日作紀（Jpn. J. Crop Sci.）86（1）：41-49（2017）

\title{
家畜排せつ物由来メタン発酵消化液の土壌施用による ネコブセンチュウ被害軽減効果の検証
}

赤木功・橒木直也

(鹿児島大学農学部)

\begin{abstract}
要旨：家畜排せつ物由来メタン発酵消化液の土壤施用によるネコブセンチュウ被害軽減効果を検証するために，いく つかの実験を試みた，消化液の成分分析の結果，採取 1 日後の消化液は殺線虫効果を持つことが報告されているアン モニア態窒素を $1.86 \mathrm{~g} \mathrm{~L}^{-1}$ 含有することが確認された。ただ，このアンモニア態窒素は採取後の貯蔵時間の経過と ともに減少していくことが示された。我が国に分布する 6 種のネコブセンチュウ（アレナリアネコブセンチュウ沖縄 型，アレナリアネコブセンチュウ本州型，キタネコブセンチュウ， サッマイモネコブセンチュウ， ジャワネコブセン チュウ，ナンヨウネコブセンチュウ）は，消化液の 5 倍希釈液の浸漬処理によって，いずれのネコブセンチュウ種も $90 \%$ 以上の個体が不動化することが示された。また，ネコブセンチュウに污染された砂丘未熟土への土壤 $1 \mathrm{~kg}$ 当り $120 \mathrm{~mL}$ (最大容水量 $60 \%$ 相当）の消化液添加は，土壤中のネコブセンチュウ密度を有意に低減させることが明らかと なった。ただし，灰色低地土抢よび黒ボク土では明確なネコブセンチュウ密度の低減効果は確認できなかった。ネコ

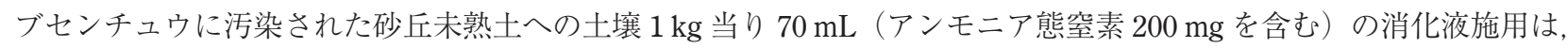
根に着生する卵のうの数を対照（化学肥料施用）の $25 \%$ 以下にまで抑制することが示された。 キーワード：ネコブセンチュウ，被害軽減，メタン発酵消化液。
\end{abstract}

現在，我が国において発生している家畜排せつ物は，年 間 8,135万 $\mathrm{t}$ と推計されており, その約 $90 \%$ 程度は農地還 元に利用できる堆肥などの有機性資材へと処理されている （農林水産省 2015）。しかし, 南九州をはじめとする畜産業 が集中している地域では，地域内の農地で還元利用できる 量を上回る家畜排せつ物が発生しており, その処理に苦慮 している.このような状況の中, 2007 年に公表された「家 畜排せつ物利用の促進を図るための基本方針」（農林水産 省 2007）に拈いて, 需要量を超えて家畜排せつ物が発生し ている地域では, エネルギー利用といった堆肥化以外の方 法によって家畜排せつ物の処理・利用を図ることが望まし いとする方針が示された。

堆肥化に代わる，エネルギー利用を目的とした家畜排せ つ物の利用技術の一つとしてメタン発酵処理が注目されて おり, 国内でも実用化が進んでいる。メタン発酵処理はバ イオマスをバイオガスプラントでメタン発酵させ, 生成し たガスをエネルギーとして利用する技術であるが，同時に 発酵残さであるメ夕ン発酵消化液（以下，消化液）が多量 に産出される．この消化液の浄化処理には BOD 除去など の水処理施設が必要であり, その運転に際しても多大なコ ストを要する，したがって，このような浄化処理以外の消 化液の有効な処理 ·利用法が求められている。 その処理 · 利用法の一つとして, 含有する肥料成分に着目した消化液 の液肥利用が水稲 $(\mathrm{Li}$ ら 2003, 上岡・亀和田 2011, Nishikawa ら 2012, Nishikawa ら 2013, Nishikawa ら 2014), 小麦（梅 津ら 2003), 飼料作物（松中ら 2003, 井戸田ら 2013), 野 菜類（中野·上原 2003, 宮田 - 池田 2006, 徳田ら 2010)
等で試みられ，その技術の普及化が進められている（農村 工学研究所 2012, 畜産環境整備機構 2013).

一方，有機物の土壤施用は作物への養分供給の他に，土 壤病害虫による作物被害の軽減に有効であることが広く知 られている。例えば, 難防除病害虫の一つである植物寄生 性線虫による作物被害に対して, 牛ふん堆肥の $10 \mathrm{a}$ 当り 1 $\mathrm{t}$ の土壤施用はキタネグサレセンチュウ発生围場に扔ける ダイコンの線虫被害を軽減させること（大林 1989）, 牛ふ ん堆肥の $10 \mathrm{a}$ 当り $10 \mathrm{t}$ の土壤施用はサツマイモネコブセン チュウ接種土壤に扔けるトマトの地上部生育量抢よび果実 収量の低下を軽減すること（中園 1989）などが報告されて いる. また, 土壤還元消毒（湛水処理）に有機物の土壌混 和を併用することで, その線虫密度低減効果をより促進さ せることも明らかにされている，例えば，豚ぷんの $10 \mathrm{a}$ 当 り $500 \mathrm{~kg}$ の土壤混和の併用によって, 土壤還元消毒のみ の場合よりも期間の短縮化およびネコブセンチュウ密度低 減効果の増強が図れること（古賀・古閑 1981）, 小麦ふす まの $10 \mathrm{a}$ 当り $2 \mathrm{t}$ の土壤混和の併用によって, 栽培後期ま でネコブセンチュウのトマトへの着生を抑制すること（久 保ら 2004）などが報告されている。このように，有機物の 土壤施用は，土壤病害虫に対する耕種的防除技術の一つと して，現在に扔いても大きな関心が向けられている。

最近, 家畜排せつ物由来の消化液についても有害線虫に よる作物被害に対して軽減効果を有することが報告されて いる. すなわち, Jothi ら（2003）はバイオガスプラントに おいて産出した消化液を $0.1 \mathrm{~kg} \mathrm{~kg}^{-1}$ の割合で土壤施用す ることによって, サツマイモネコブセンチュウによるトマ

2016 年 6 月 30 日受理. 連絡責任者: 赤木功 $\bar{\top} 890-0065$ 鹿児島県鹿児島市郡元 1-21-24

TEL 099-285-8663, akagi046@chem.agri.kagoshima-u.ac.jp 
卜の寄生被害を軽減できることをポット栽培によって明ら かにしている。また，Min ら（2007）は消化液の 48 時間 の浸漬処理によって, サッマイモネコブセンチュウの生存 率が低下することを試験管試験によって明らかにしてい る。ただし，現在のところ，消化液のネコブセンチュウに 対する効果に関する研究事例はこれらに限られており，そ の知見は断片的である. 生産現場での利用普及のためには, この効果についてのより詳細な実証事例の蓄積が必要であ る。ネコブセンチュウは農業生産上最も重要な植物寄生性 線虫の一つであり，寄主範囲が極めて広いため，国内に㧈 いても畑作物や野菜類など数多くの作物に対してして多大 な被害を及ぼしている（吉田 1992）。特に，モントリオー ル議定書締約国会合において，土壤くん蒸剤である臭化メ チルが全廃されたことに伴い, ネコブセンチュウによる作 物被害のさらなる拡大が懸念されている。したがって, 消 化液の土壤施用によるネコブセンチュウ被害の軽減の効果 が実証されれば，消化液のさらなる利用拡大が図れるもの と考える

そこで本研究では，日本国内に分布するネコブセンチュ ウ 6 種を用いて，消化液の浸漬処理が活動性に及ぼす影響 を調査するとともに，土壤型の異なる 3 タイプの土壤を用 いて, 消化液の土壤施用がサツマイモネコブセンチュウの 土壤中密度に及ぼす影響を検証した。ささらに，消化液の土 壤施用によるトマト幼植物のネコブセンチュウ被害軽減効 果について検討を行った。

\section{材料と方法}

\section{1. 消化液中の有機酸およびアンモニア態窒素の濃度と その経時変化（試験 1)}

本研究では, 鹿児島県鹿屋市のメタン発酵処理施設で産 出された消化液を用いた。この処理施設では豚ぷん尿を主 体とする家畜排せつ物を原材料としている，なお，ここで 採取した消化液はエアレーション処理を行う前のものであ る.

試験 1 では，この消化液に含まれる有機酸およびアンモ ニア態窒素の濃度を経時的に測定した。はじめに, 採取後 室温で 1 日経過したものについて測定を行った。 その後, 消化液をポリ容器に採り密栓した後, 室温および冷蔵 $\left(4{ }^{\circ} \mathrm{C}\right)$ 条件下で保存した。そして，採取 $10 ， 20$ および50 日経過 したものについて同様に測定を行った，消化液は遠心分離 $(4000 \times \mathrm{g}, 30$ 分) によって懸濁物質を沈降させ, 得られた 上澄みをメンブランフィルター $(40 \mu \mathrm{m}, \mathrm{ADVANTEC}$ 社製 $)$ でろ過したものを分析に供した，有機酸濃度は陰イオン交 換カラム（Ion Pac AS14A, Thermo Scientific 社製）を装着 したサプレッサー式イオンクロマトグラフ（ICS-900, Thermo Scientific 社製）で測定した。アンモニア態窒素は インドフェノール改良法（荒川ら 2003）で測定した.

\section{2. 消化液の浸漬処理がネコブセンチュウの活動性に及 ぼす影響（試験 2)}

ネコブセンチュウ試料として，日本国内に生息することが 知られているアレナリアネコブセンチュウ沖縄型（M. arenari (Neal) Chitwood, Okinawa-type), アレナリアネコブセンチュ ウ本州型 (M. arenaria (Neal) Chitwood, Honshu-type), キタ ネコブセンチュウ (M. hapla Chitwood), サッマイモネコブセ ンチュウ (M. incognita (Kofoid and White) Chitwood), ジャ ワネコブセンチュウ（M. javanica（Treub）Chitwood）および ナンヨウネコブセンチュウ (M. microcephalus Cliff and Ichinohe) の 6 種を用いた。いずれも九州沖縄農業研究センター線虫害 研究グループ 岩堀英晶博士 (現在 龍谷大学農学部) より分 譲されたものを著者らが継代飼育したものである。

ふ化後 5 日以内のネコブセンチュウ約 150 頭をガラス試 験管に採り，原液の 5 倍， 10 倍，50 倍および 100 倍に希

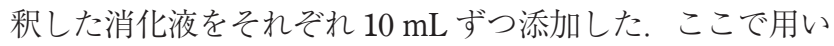
た消化液の試験開始時におけるアンモニア態窒素濃度は $2.49 \mathrm{~g} \mathrm{~L}^{-1}$ であり, 酢酸, プロピオン酸などの有機酸は検 出されなかった，また，対照として蒸留水のみ加えた試験 区を設定した，消化液ないし蒸留水を添加したガラス試験 管は $25^{\circ} \mathrm{C}$ に設定したインキュベーター内で静置した， 24 時間経過後, 顕微鏡下で運動性のないネコブセンチュウと 運動性のあるネコブセンチュウに分けて計数し, 総ネコブ センチュウに対する運動性のないネコブセンチュウの割合 を不動化率として算出した. 以上の実験は 5 反復で行った。

\section{3. 消化液の土壤施用がネコブセンチュウの土㙵中密度 に及ぼす影響（試験 3)}

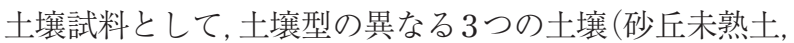
灰色低地土㧍よび黒ボク土）を用いた，砂丘未熟土は宮崎 大学農学部住吉フィールド (宮崎県宮崎市), 灰色低地土 は鹿児島大学農学部附属農場（鹿児島県鹿児島市）, 黒ボ ク土は鹿児島県総合農業開発センター実験围場（鹿児島県 南さつま市）からそれぞれ採取したものである。これらの 土壤にサッマイモネコブセンチュウを接種し，ミニトマト （品種：プリッツ）を6 ケ月以上栽培することで，ネコブ センチュウ密度を高めた污染土壤をそれぞれ準備した。

根などの夾雑物を除去した污染土壤 $0.25 \mathrm{~kg}$ を直径 $9 \mathrm{~cm}$ のポリポットに充填し, 消化液を最大容水量 $60 \%$ 相当，す なわち, 土壤 $1 \mathrm{~kg}$ 当り $128 \mathrm{~mL}$ (砂丘未熟土), $348 \mathrm{~mL}$ (灰 色低地土）ないし $368 \mathrm{~mL}$ (黒ボク土)をそれぞれ施用した。 消化液は，原液そのままのもの，原液を 2 倍および 5 倍に 希釈したものを用いた。この時に用いた消化液のアンモニ ア態窒素濃度は $1.88 \mathrm{~g} \mathrm{~L}^{-1}$ であり, 酶酸, プロピオン酸な どの有機酸は検出されなかった，また，対照として消化液 を施用せず，代わりに蒸留水を加えた試験区を設定した。 それぞれ処理を施したポリポットは $25^{\circ} \mathrm{C} に$ 設定したイン キュベーター内で静置し，7日経過した後にベールマン法 によって活動性を有する線虫を分離し（佐野 2014），顕微 
第 1 表 ミニトマト幼植物栽培試験（試験 4）におけるメタン発酵消化液および化学肥料施用量.

\begin{tabular}{|c|c|c|c|c|c|c|}
\hline & \multicolumn{3}{|c|}{ 土壤 $1 \mathrm{~kg}$ 当り施用量 } & \multicolumn{3}{|c|}{ 試験区（土䁃 $4.2 \mathrm{~kg}$ ) 当り施用量 } \\
\hline & $\begin{array}{c}\text { 消化液 * } \\
(\mathrm{mL})\end{array}$ & $\begin{array}{c}\text { 化学肥料 ** } \\
(\mathrm{g})\end{array}$ & $\begin{array}{c}\text { アンモニア態窒素 } \\
\text { 添加量 }(\mathrm{mg})\end{array}$ & $\begin{array}{c}\text { 消化液 * } \\
(\mathrm{mL})\end{array}$ & $\begin{array}{c}\text { 化学肥料 ** } \\
(\mathrm{g})\end{array}$ & $\begin{array}{c}\text { アンモニア態窒素 } \\
\text { 添加量 }(\mathrm{mg})\end{array}$ \\
\hline 消化液施用：N100 区 & 35 & - & 100 & 147 & - & 419 \\
\hline 消化液施用：N200 区 & 70 & - & 200 & 294 & - & 838 \\
\hline 対照区 & - & 0.62 & 99 & - & 2.6 & 416 \\
\hline
\end{tabular}

*消化液（アンモニア態窒素濃度 $: 2.85 \mathrm{~g} \mathrm{~L}^{-1}$ )，**粒状配合肥料（アンモニア態窒素含量： $160 \mathrm{~g} \mathrm{~kg}^{-1}$ ).

第 2 表 メタン発酵消化液中の有機酸およびアンモニア態窒素濃度の経時変化.

\begin{tabular}{|c|c|c|c|c|c|c|}
\hline \multirow{2}{*}{ 経過日数 } & \multirow{2}{*}{ 保存条件 } & \multicolumn{4}{|c|}{ 有機酸成分 $\left(\mathrm{mg} \mathrm{L}^{-1}\right)$} & \multirow{2}{*}{$\begin{array}{c}\text { アンモニア態窒素 } \\
\left(\mathrm{mg} \mathrm{L}^{-1}\right)\end{array}$} \\
\hline & & ギ酸 & 酢酸 & プロピオン酸 & 酪酸 & \\
\hline 採取 1 日後 & 室温保存 & n.d. & 141 & 14.5 & n.d. & 1.86 \\
\hline \multirow{2}{*}{ 採取 10 日後 } & 室温保存 & n.d. & 4 & n.d. & n.d. & 1.84 \\
\hline & 冷蔵保存 & n.d. & 1 & n.d. & n.d. & 1.78 \\
\hline \multirow{2}{*}{ 採取 20 日後 } & 室温保存 & n.d. & n.d. & n.d. & n.d. & 0.84 \\
\hline & 冷蔵保存 & n.d. & n.d. & n.d. & n.d. & 1.05 \\
\hline \multirow{2}{*}{ 採取 50 日後 } & 室温保存 & n.d. & n.d. & n.d. & n.d. & 0.18 \\
\hline & 冷蔵保存 & n.d. & n.d. & n.d. & n.d. & 0.24 \\
\hline
\end{tabular}

n.d. は検出限界未満であることを示す.

鏡下で総線虫数およびネコブセンチュウ数をそれぞれ計測 した，以上の実験は 3 反復で行った.

\section{4. 消化液の土袞施用によるミニトマト幼苗のネコブセ ンチュウ被害軽減効果の検証（試験 4)}

土壤試料として, 試験 3 と同様の方法で調製した, 砂丘 未熟土のネコブセンチュウ污染土壤を用いた．根などの夾 雑物を除去した污染土壤 $4.2 \mathrm{~kg}$ をプラスチックコンテナ $(195 \mathrm{~mm} \times 320 \mathrm{~mm} \times 100 \mathrm{~mm})$ に充填し, 土壤全体が十分 に湿るように灌水を行った，その後，窒素施用量が土壤 1 $\mathrm{kg}$ 当り $100 \mathrm{mg}$ 抢よび $200 \mathrm{mg}$ となるように，消化液をそ れぞれ $147 \mathrm{~mL}$ および $294 \mathrm{~mL}$ ずつ施用した（第 1 表）。こ の時に用いた消化液のアンモニア態窒素濃度は $2.85 \mathrm{~g} \mathrm{~L}^{-1}$ であった。また，対照として窒素施用量が土壤 $1 \mathrm{~kg}$ 当り 約 $100 \mathrm{mg}$ となるように粒状配合肥料 $\left(\mathrm{N}: \mathrm{P}_{2} \mathrm{O}_{5}: \mathrm{K}_{2} \mathrm{O}=\right.$ $16 \%: 16 \%: 16 \%$, 有機態成分は含まない）を施用したコ ンテナを設けた。土壤施用を行った翌日にミニトマト（品 種：プリッツ）の幼苗（本葉第 3〜4 葉展開期）を定植し, 最低気温を $20^{\circ} \mathrm{C}$ 以上に保ったガラス温室内で栽培を開始 した，定植後 43 日後にミニトマトを掘り上げ，よく根を 洗いフロキシン B で卵のうを染色した後，根に着生してい る卵のうの数を計測した，以上の実験は 4 反復で行った.

\section{結果と考察}

\section{1. 消化液中の有機酸およびアンモニア態窒素の濃度と その経時変化（試験 1)}

消化液中の有機酸抢よびアンモニア態窒素濃度の経時変
化を第 2 表に示した。採取 1 日後の消化液は，有機酸とし て酶酸を $141 \mathrm{mg} \mathrm{L}^{-1}$ ，プロピオン酸を $15 \mathrm{mg} \mathrm{L}^{-1}$ ，また，ア ンモニア態窒素を $1.86 \mathrm{~g} \mathrm{~L}^{-1}$ 含有していた。ギ酸掞よび酪 酸は検出されなかった。酢酸は採取 10 日後には大きく減 少し, その濃度は室温保存で $4.3 \mathrm{mg} \mathrm{L}^{-1}$, 冷蔵保存で 1.0 $\mathrm{mg} \mathrm{L}^{-1}$ であった。 プロピオン酸は室温保存, 冷温保存のい ずれにおいても検出限界未満であった。採取 20 日後には 酢酸も検出限界末満にまで減少した。一方，アンモニア態 窒素は, 採取 10 日後に扔いても室温保存で $1.84 \mathrm{~g} \mathrm{~L}^{-1}$, 冷 蔵保存で $1.78 \mathrm{~g} \mathrm{~L}^{-1}$ 含有していた。しかし, 採取 20 日後 には室温保存で $0.84 \mathrm{~g} \mathrm{~L}^{-1}$, 冷蔵保存で $1.05 \mathrm{~g} \mathrm{~L}^{-1}$ にまで 減少し, さらに採取 50 日後には室温保存で $0.18 \mathrm{~g} \mathrm{~L}^{-1}$, 冷 温保存で $0.24 \mathrm{~g} \mathrm{~L}^{-1}$ となった。

分子量の小さい有機酸である短鎖脂肪酸はイシュクセン チュウ, ナガハリセンチュウ，ネコブセンチュウ，ネグサ レセンチュウ, マツノザイセンチュウ，ラセンセンチュウ などの有害線虫に対して殺線虫活性を示すことが明らかに されている（Johnston 1959， Nagase ら 1982，Bansal and Bajaj 2003, Browning ら 2004, McElderry ら 2005, Min ら 2007, Katase ら 2009). 短鎖脂肪酸の浸漬処理による殺線虫作用 の検証試験によれば, $6 \mathrm{mmol} \mathrm{L}^{-1}\left(360 \mathrm{mg} \mathrm{L}^{-1}\right)$ および 8 $\mathrm{mmol} \mathrm{L}^{-1}\left(480 \mathrm{mg} \mathrm{L}^{-1}\right)$ の酢酸の添加によって, サッマイモ ネコブセンチュウの 24 時間後の生存率はそれぞれ $12 \%$ お よび $5 \%$ にまで低下することが示されている (katase ら 2009）。消化液には，上述のように，殺線虫活性を示す酢 酸が含まれていたが，その濃度は最も高かった採取 1 日後 のものでも $141 \mathrm{mg} \mathrm{L}^{-1}$ であり，その活性を期待するには十 
アレナリアネコブセンチュウ (本州型)
アレナリアネコブセンチュウ (沖縄型)
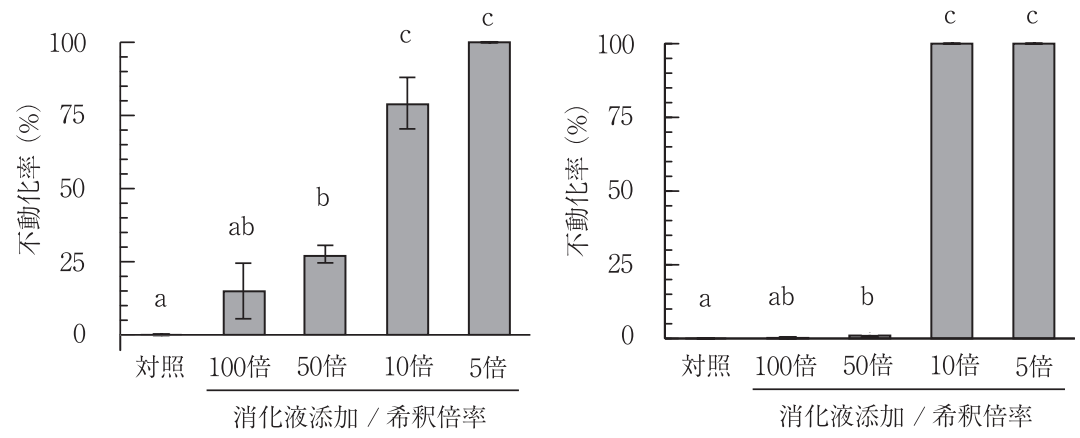

サツマイモネコブセンチュウ

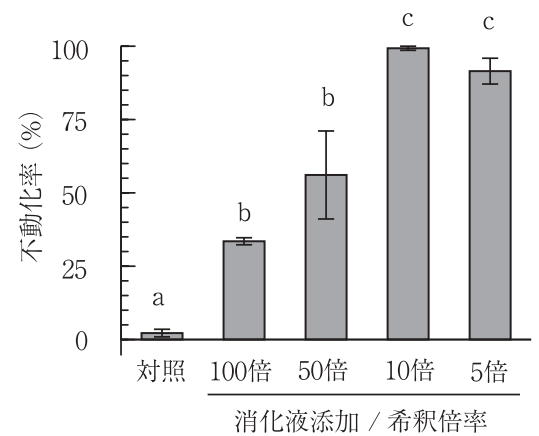

ジャワネコブセンチュウ

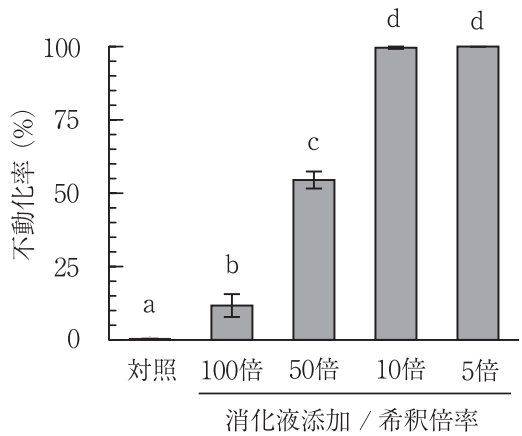

キタネコブセンチュウ

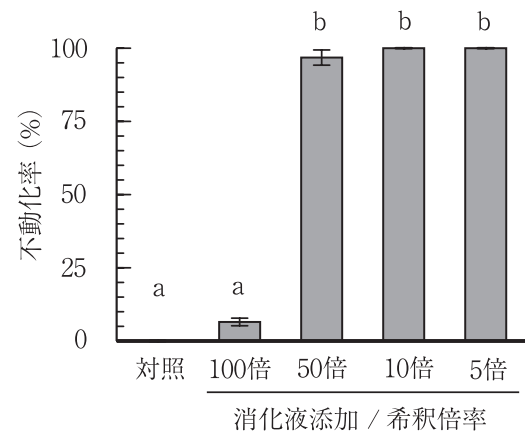

ナンヨウネコブセンチュウ

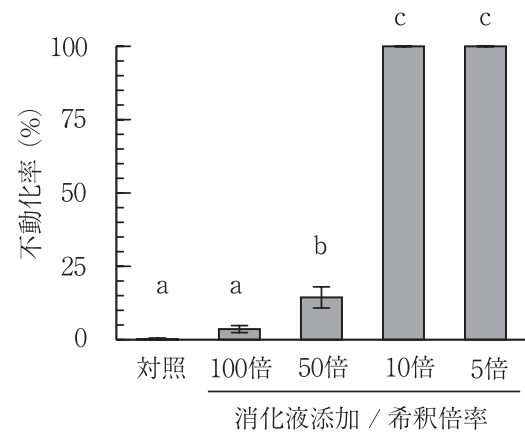

第 1 図 メタン発酻消化液の浸漬処理によるネコブセンチュウの不動化効果.

各図の同一アルファベット間には 5\%水準で有意差がないことを示す（Tukey WSD 法, $\mathrm{n}=5$ ).

分な濃度ではないと考えられる。また，消化液は $\mathrm{pH} 7.6$ 〜 8.0 程度のアルカリ性を示すが，短鎖脂肪酸はそれらの 多くが解離したイオンの形で存在する $\mathrm{pH} 6$ 以上の条件下 ではネコブセンチュウに対してほとんど殺線虫活性を示さ ないことが報告されている（Katase ら 2009）。このことか らも，消化液に含有する酢酸が直接的にネコブセンチュウ に対して殺抗菌活性を示す可能性は小さいものと予想され る.

一方，アンモニアも水生生物に対する毒性が強いことが 知られており (田端 1979), 短鎖脂肪酸と同様に有害線虫 に対して殺線虫活性を示すことが報告されている（Nagase ら 1982, Min ら 2007)。 アンモニアの浸漬処理による殺線 虫作用の検証試験によれば, $1 \mathrm{mg} \mathrm{L}^{-1}$ および $10 \mathrm{mg} \mathrm{L}^{-1}$ のア ンモニアの添加によって, キタネグサレセンチュウの 48 時間後の生存率はそれぞれ $60 \%$ （5 頭中 2 頭が死滅）およ び 0\%（5 頭中すべてが死滅）にまで低下することが示さ れている (Min ら 2007). 本研究の測定結果によれば, 採 取 1 日後の消化液にはアンモニア態窒素が $1.86 \mathrm{~g} \mathrm{~L}^{-1}$ 含ま れており，消化液の $\mathrm{pH}$ 条件下（pH 7.6 8.0）では少な くとも $10 \mathrm{mg} \mathrm{L}^{-1}$ を回るアンモニアが存在していると考 えられることから, この消化液中のアンモニアがネコブセ ンチュウの活動性に対して何らかの抑制効果を示す可能性 があると推察される。

しかし，消化液に含まれるアンモニア態窒素は，採取 20
日後には採取 1 日後における濃度の $57 \%$ （冷蔵保存）ない し 45\%（室温保存），採取 50 日後には 13\%（冷蔵保存）な いし10\%（室温保存）にまで濃度が低下した，消化液中の アンモニア態窒素の経時的減少の原因として, 消化液から のアンモニアとしての揮散が考えられる．消化液は前述の ようにアルカリ性を示し，アンモニアによる揮散が生じや すい条件にあるといえる，このように，消化液採取後の経 過時間が長くなるほどアンモニア態窒素濃度が減少するこ とは，消化液の貯蔵期間が長くなるほどネコブセンチュウ に対する殺線虫作用が減退する可能性があることを予想さ せる. 消化液の貯蔵期間とネコブセンチュウへの効果との 関係性については, 今後, 詳細に検証する必要があると考 える.

\section{2. 消化液の浸漬処理がネコブセンチュウの活動性に及 ぼす影響（試験 2)}

消化液の浸漬処理による 6 種のネコブセンチュウに対す る不動化効果の試験結果を第 1 図に示した． 5 倍に希釈し た消化液の浸漬によるネコブセンチュウの不動化率は，ア レナリアネコブセンチュウ沖縄型, アレナリアネコブセン チュウ本州型, キタネコブセンチュウ, ジャワネコブセン チュウおよびナンヨウネコブセンチュウが $100 \%$, サッマ イモネコブセンチュウが $92 \%$ あ゙あ， いずれのネコブセ ンチュウ種も $90 \%$ 以上の高い不動化効果を示した. 10 倍 
砂丘未熟土 / 全線虫

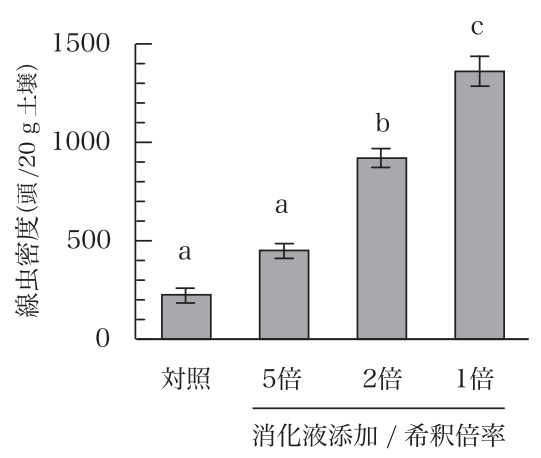

砂丘未熟土 / ネコブセンチュウ

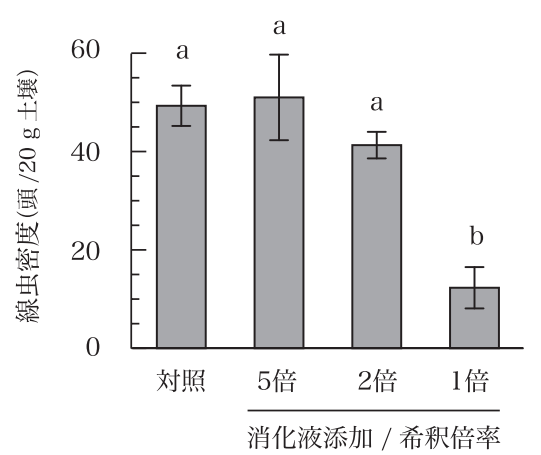

灰色低地土 / 全線虫

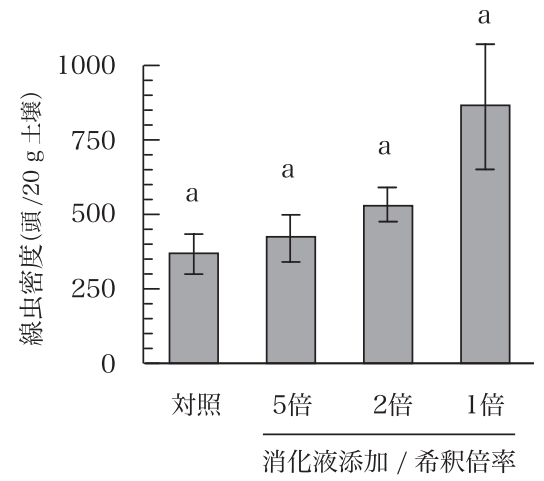

灰色低地土 / ネコブセンチュウ

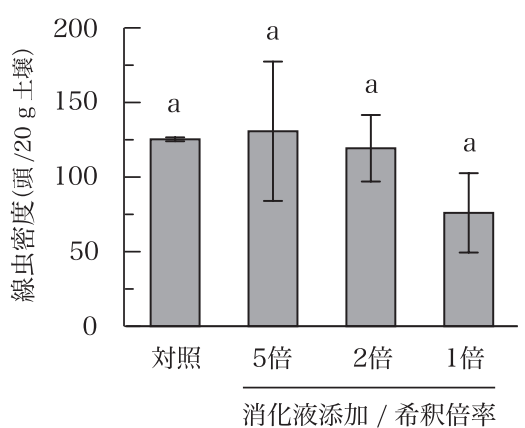

黒ボク土 / 全線虫

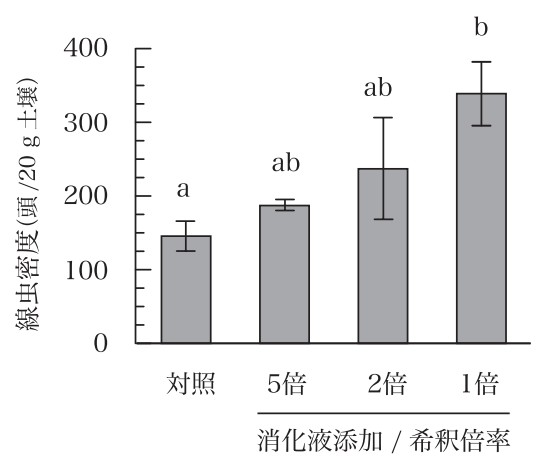

黒ボク土/ネコブセンチュウ

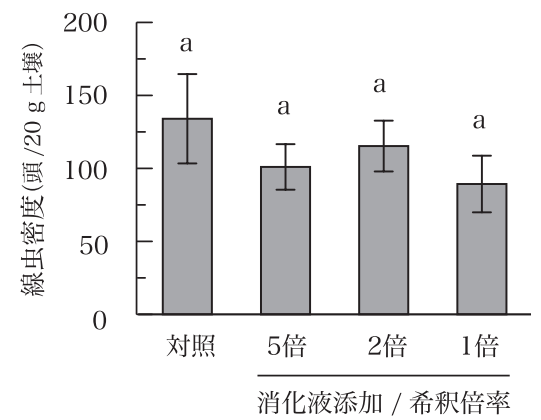

第 2 図 メタン発酵消化液の土䁃施用が土壤中の線虫密度に及ぼす影響.

上段は全線虫密度，下段はネコブセンチュウ密度を示す。また，各図の同一アルファベット間には $5 \%$ 水準で有意差がないこ とを示す (Tukey HSD 法, $\mathrm{n}=3$ ).

に希釈した消化液の浸漬では，アレナリアネコブセンチュ ウ本州型が $79 \%$ とやや低かったものの，それ以外のネコ ブセンチュウ種は $90 \%$ 以上の高い不動化率を示した. 50 倍に希釈した消化液ではネコブセンチュウ種によって不動 化率に差が認められ，キタネコブセンチュウは $97 \%$ と高 い不動化効果を示したのに対し, サッマイモネコブセン チュウは $56 \%$ ，ジャワネコブセンチュウは $55 \%$ ，アレナ リアネコブセンチュウ本州型は $28 \%$ ，ナンヨウネコブセ ンチュウは $14 \%$ ，アレナリアネコブセンチュウ沖縄型は $1 \%$ 程度であった。 100 倍に希釈した消化液による浸漬では 十分な不動化効果は得られず，その不動化率はサツマイモ ネコブセンチュウが $34 \%$ ，アレナリアネコブセンチュウ 本州型が $15 \%$ ，ジャワネコブセンチュウが $11 \%$ ，キタネ コブセンチュウが $7 \%$ ，ナンヨウネコブセンチュウが $4 \%$, アレナリアネコブセンチュウ沖縄型が $1 \%$ 未満であった。

以上のように，消化液による浸漬がネコブセンチュウに 対して不動化効果を示すことは, Min ら（2007）がサッマ イモネコブセンチュウを用いた試験で有効性を確認してい るが, アレナリアネコブセンチュウ沖縄型, アレナリアネ コブセンチュウ本州型, キタネコブセンチュウ， ジャワネ コブセンチュウおよびナンヨウネコブセンチュウなどの我 が国に分布する複数のネコブセンチュウ種に対しても5 倍 希釈程度の消化液で十分な不動化効果を示すことが本研究
によって確証された。なお，上述の Minら（2007）の報告 では, アンモニア態窒素濃度 $100 \mathrm{mg} \mathrm{L}^{-1}$ の消化液の浸漬処 理で 5 頭中 3 4 頭（不動化率：60 80\%）のサッマイモ ネコブセンチュウが不動化したと述べられている. 本研究 において, 99\%の不動化を示した消化液の 10 倍希釈液に は $249 \mathrm{mg} \mathrm{L}^{-1}, 56 \%$ の不動化率を示した 50 倍希勫液には 49. $8 \mathrm{mg} \mathrm{L}^{-1}$ のアンモニア態窒素がそれぞれ含有していた ものと計算されるが，このアンモニア態窒素濃度とサッマ イモネコブセンチュウの不動化率との関係はその報告と概 ね一致するものであるといえる。

消化液の浸漬処理によって不動化したネコブセンチュウ の形態を観察すると, いずれのネコブセンチュウ種も体内 に大きな液胞が生じていることが認められた（デー夕省 略)。このような現象は, 田場ら（2012）によって詳細に 述べられている。 すなわち, 抗線虫活性を有するアワユキ センダングサ抽出液でネコブセンチュウを浸漬処理した場 合, 体内に多数の液胞が形成されることを報告するととも に，このような現象はマツノザイセンチュウの成虫をフェ ノール溶液に浸漬した場合（畑田ら 1981），また，二セネ グサレセンチュウに乾燥ストレスを与えた場合（石橋 2003）にも生じることから, 外部から何らかの生存に不利 な刺激を受けた時に生じる線虫の反応の一つであると推察 している，消化液がネコブセンチュウに対してどのような 
作用機序で不動化効果を起こしているのかについては，本 研究の結果からは予想できないが，このようなネコブセン チュウの形態反応がこれを解くための手がかりとなるかも しれない.

\section{3. 消化液の土壤施用がネコブセンチュウの土壤中密度 に及ぼす影響（試験 3)}

消化液の土壤施用が土壤中ネコブセンチュウ密度（土䁃 $20 \mathrm{~g}$ 当りの 2 令幼虫頭数）に及ぼす影響について調査した 結果を第 2 図に示した. 砂丘未熟土において，2 倍拉よび 5 倍に希釈した消化液の土壤施用ではネコブセンチュウ密 度の低下は認められなかったが, 消化液原液の施用は消化 液無施用の対照区よりも有意にネコブセンチュウ密度が低 下した。すなわち, 対照区のネコブセンチュウ密度が 49.3 頭であったのに対し, 消化液原液を施用した試験区 は 12.3 頭にまで低下した。このことは，消化液の土壤施 用は土壤中のネコブセンチュウ密度を抑制する効果がある ことを示唆している. なお, この時の消化液の土壤施用量 は土壤 $1 \mathrm{~kg}$ 当り消化液 $128 \mathrm{~mL}$ であることから, 土壤 $1 \mathrm{~kg}$ 当りアンモニア態窒素を $241 \mathrm{mg}$ 施用した計算となる。

しかし一方，灰色低地土および黒ボク土では，5倍希釈， 2 倍希釈および原液のいずれの濃度においても, 消化液の 土壤施用によってネコブセンチュウ密度を有意に低下させ ることはできなかった。このように土壤の違いによって, ネコブセンチュウ密度に対する効果に差異が生じた原因は 明らかではないが, 土壤の特性の違いがその一つの要因と なっているのかもしれない，例えば，灰色低地土や黒ボク 土は, 砂丘未熟土に比べて団粒構造が発達しており, 多数 の孔隙が形成されている. 団粒構造は土壤細菌などの土壤 微生物の生存性に大きく関与していることが知られてお り, 外部から添加された酸などに対し団粒構造内部に生息 する細菌を保護する効果をもつことが報告されている（石 塚ら 1995). サッマイモネコブセンチュウ 2 令幼虫はふ化 後, 団粒内部に形成された孔隙へ移動する傾向をもつこと, また，団粒内部にはネコブセンチュウが長期生存に適する ような生理的変化を起こしやすい条件が存在する可能性が あることが報告されている（佐野・中園 1997a, b)。このよ うな土壤微細構造の発達程度が消化液に対するネコブセン チュウの生存性に大きな影響を及ぼしている可能性は十分 に考えられる。このように, 消化液の土壤施用によるネコ ブセンチュウ密度低減効果は, 土䁃特性の違いによって効 果が大きく異なることが示された，実用にあたっては，土 壤型によって消化液のネコブセンチュウ密度軽減効果が異 なることに注意しなければならない，

一方, 興味深いことに, 土壤中の全線虫密度は消化液の 土潩施用によって上昇する傾向にあり, 砂丘未熟土および 黒ボク土では消化液原液の土壤施用は対照区と比較して有 意に全線虫密度が上昇することが確認された。すなわち, 砂丘未熟土では 206 頭から 1346 頭, 黒ボク土では 191 頭
第 3 表 メタン発酵消化液の土壤施用がミニトマト幼苗の根に着生 するネコブセンチュウの卵のう数に及ぼす影響.

\begin{tabular}{cccc}
\hline & 卵のう数 & \multicolumn{2}{c}{ 新鮮重 $(\mathrm{g})$} \\
\cline { 3 - 4 } & $\left(\right.$ No. plant $\left.{ }^{-1}\right)$ & 地上部 & 根部 \\
\hline 消化液施用 N 100 & $190 \pm 69^{\mathrm{a}}$ & $7.2 \pm 2.6^{\mathrm{a}}$ & $3.1 \pm 0.4^{\mathrm{a}}$ \\
消化液施用 N 200 & $52 \pm 9 \mathrm{~b}$ & $9.9 \pm 5.6^{\mathrm{a}}$ & $2.9 \pm 0.2^{\mathrm{a}}$ \\
対照 & $244 \pm 82^{\mathrm{a}}$ & $6.6 \pm 3.5^{\mathrm{a}}$ & $2.6 \pm 0.6^{\mathrm{a}}$ \\
\hline
\end{tabular}

各項目の同一アルファベット間には $5 \%$ 水準で有意差がないことを 示す (Tukey HSD 法, $\mathrm{n}=4$ ).

から 347 頭にそれぞれ増加していた。灰色低地土において も, 有意な差ではないものの, 消化液原液の土壤施用によっ て全線虫数が 280 頭から 780 頭へと増加する傾向が認めら れた。このことは, 消化液の土䁃施用が線虫の土壤中密度 に及ぼす影響は線虫種間で差異があることを示している。 堆肥などの有機物の施用は, 土壤中の自活性線虫の密度を 高めることが知られている (Linfordら 1938). 消化液には メ夕ン発酵に関与する細菌群が多量に含まれているが，そ の土壤施用は土壤中に生息する細菌食性の自活性線虫の増 加を引き起こすことを予想させる，本調査では，ネコブセ ンチュウ以外の線虫種について識別・同定を行っていない ので，十分に議論することはできないが，このような自活 性線虫の増加が土壤中の総線虫密度の増加として表れた可 能性があるとものと推察される。自活性線虫は土壤生態系 における構成生物種の一つとして重要な役割を担ってお り，土壤環境における物質循環に大きく寄与している (Ingham ら 1985, Ferris ら 1998, 岡田 2002). また, 自活 性線虫が土壤病害や植物寄生性線虫の活動性に少なからず 影響を及ぼすことが知られており（Ishibashi and Choi 1991， Nahar ら 2006, Khan and Kim, 2007), 自活性線虫の維持 は特定の病害虫の異常な増殖を抑制する働きがあるものと 考えられている。 さらなる詳細な調査が必要であるが, 消 化液は自活性線虫の密度に大きな負の影響を及ぼすことな く, ネコブセンチュウなどの特定の線虫に対して効果をも つリサージェンスを起こしにくい資材として期待される。

\section{4. ネコブセンチュウによるミニトマト幼苗の被害軽減 効果（試験 4)}

試験終了時（定植 43 日後）に扔ける，それぞれの試験 区の植物体の新鮮重㧍よび根に着生した卵のう数を第 3 表 に示した。ミニトマトの生育は, 試験区間で大きな差は認 められず, 化学肥料を施用したもの (対照区), 土壤 $1 \mathrm{~kg}$ 当りアンモニア態窒素 $100 \mathrm{mg}$ 相当抢よび $200 \mathrm{mg}$ 相当の消 化液を施用したもの（それぞれN100 区およびN200 区） の間で地上部および根部の新鮮重に大きな差は認められな かった。一方, 根に着生した卵のう数は，N100区では対 照区と明瞭な違いは認められなかったが, N200 区では有 意に少なかった。すなわち, 対照区の着生卵のう数は 1 個 体当り 244 個であったのに対し, N200 区は 52 個にまで減 

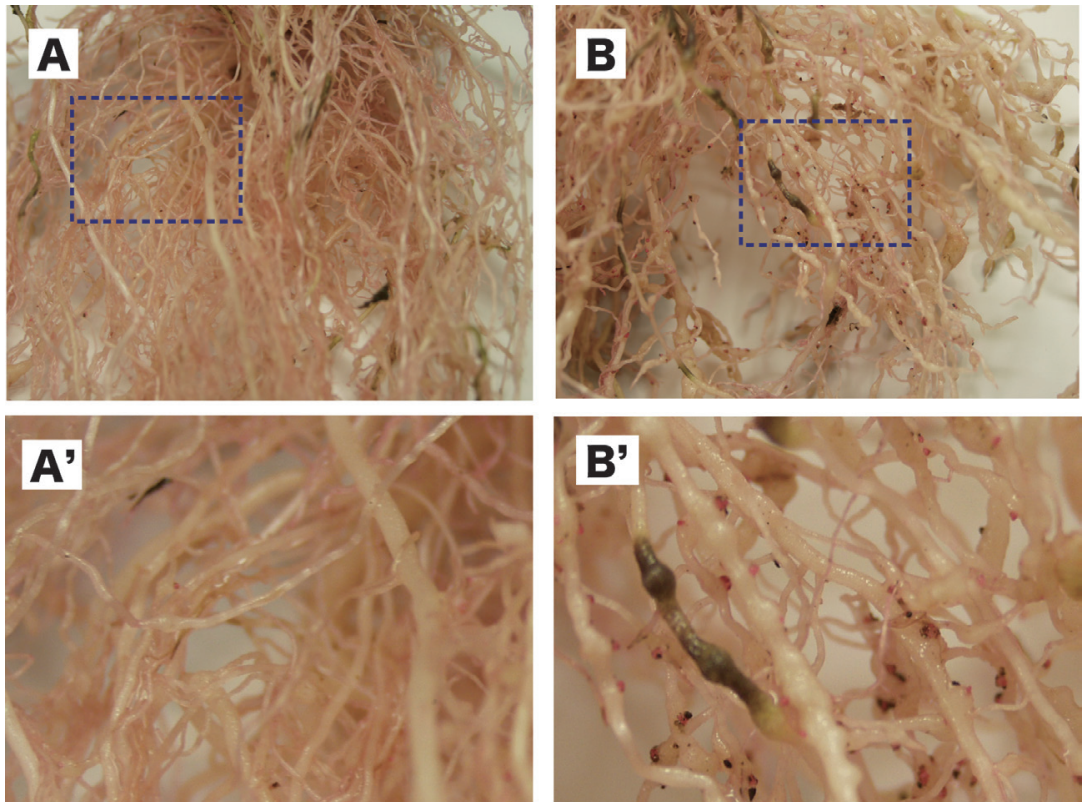

第 3 図 ミニトマト幼植物栽培試験（試験 4）終了時における消化液添加（N 200）区（A および $\left.\mathrm{A}^{\prime}\right)$ と対照区（B および $\mathrm{B}^{\prime}$ ) の根の状態の比較.

A'および $\mathrm{B}^{\prime}$ は， $\mathrm{A}$ および $\mathrm{B} の 一$ 部（点線の枠内）をそれぞれ拡大したもの.

対照区（B および B'）と比較して, 消化液添加（N200）区（A および $\mathrm{A}^{\prime} ）$ は根こ ぶが少なく，細根が維持されている。なお，ネコブセンチュウの卵のうはフロキ シン Bによって赤く染色されている.

少し，対照区の $21 \%$ 程度にまで卵のうの着生が抑制され ていた。

N200 区と対照区の根の状態を比較した写真を第 3 図に 示した，対照区は根系全体にわたって根こぶが連なって形 成され，根が太くなっていたのに対し，N200 区は根こぶ の数も少なく, 細い根が維持されていた.

以上のように, ミニトマト幼植物の栽培試験では, 土壤 $1 \mathrm{~kg}$ 当りアンモニア態窒素 $200 \mathrm{mg}$ 相当を含む消化液, す わなち土壤 $1 \mathrm{~kg}$ 当り $70.2 \mathrm{~mL}$ の消化液の土壤施用によっ て，ネコブセンチュウ卵のう着生数を $25 \%$ 以下の程度に まで抑制する効果が認められた。この時の消化液の施用量 を $10 \mathrm{a}$ 当りに換算すると, 約 $7 \mathrm{~kL}$ の消化液の施用が必要 となるものと計算される(作土 $10 \mathrm{~cm}$, 土壤容積重 $1 \mathrm{~g} \mathrm{~cm}^{-3}$ とした場合)。畑地に扔いて消化液を液肥利用する場合， 表面流出による施肥ムラを防ぐためには, 最大で 1 回当り 5 6 kL 程度の施用が望ましいとされているが（農村工学 研究所 2012), 上述のネコブセンチュウ卵のう形成抑制効 果が期待される消化液施用量（10 a 当り $7 \mathrm{~kL}$ ) はこれを大 きく上回る量ではなく，十分に適用可能な量であると考え られる。なお，消化液は液肥としての利用が試みられてい るように, アンモニア態窒素をはじめとした肥料成分を含 有している。 また, 家畜排せつ物を原材料とする消化液は, 家畜排せつ物に由来する亜鉛や銅等の重金属を含んでいる 場合がある。したがって，適正レベルを超えた継続的な消 化液の土壤施用は，肥料成分および重金属の土壤蓄積およ びその溶脱・拡散による環境污染を生じさせるリスクがあ
る. 実用にあたっては, 消化液から負荷される肥料成分な らびに重金属等を考慮して, 消化液の施用量を決定する必 要がある.

以上の結果は, コンテナを用いた栽培試験によるもので あるが, 消化液の土壤施用によるネコブセンチュウの被害 軽減効果について，このような植物を用いた生物検定にお いて有効性が示されたことは意義深い.ただし，これは砂 丘未熟土を供試土壤として用いた結果であり, 試験 3 にお いてネコブセンチュウ密度抑制効果が認められなかった灰 色低地土や黒ボク土でも同様の成果が得られるかについて は, さらに検証を進める必要がある。 なお, ネコブセンチュ ウによる作物被害は砂質の土壤で大きい傾向にあることが 知られており（川島 1961, 中園ら 1989, 中園ら 1990), 例 えば，石川県内の砂丘地域におけるメロン，トマト等の施 設栽培（清水ら 2006）, 千葉県内の砂質土壤地域に扮ける トマト等の施設栽培（大嵩・若梅 2006), 南九州地域の砂 丘未熟土地域に扔けるピーマンの施設栽培（赤木・橒木 2014）などでネコブセンチュウによる被害が多発している ことが報告されている，消化液の土壤施用によるネコブセ ンチュウ被害の軽減技術は, このような砂質土壤からなる 戋場において有効に活用できるものと考えられる。

メタン発酵処理は家畜排せつ物などの未利用バイオマス の有効利用のための技術として期待されているが, その普 及にはメタン発酵処理の過程で産出される消化液の利用促 進が必要である．消化液の液肥としての作物栽培への利用 の有効性は, 飼料作物をはじめとした各種作物で実証され, 
その利用技術の普及が図られている。本研究では，以上の ように，適用する土壤特性によって効果に差が認められる ものの，砂質の土壤では消化液を土壤施用することで国内 に分布する主要なネコブセンチュウによる作物被害を軽減 できる可能性が示された。このことは消化液の液肥利用に 対して，ネコブセンチュウ被害軽減効果という新たな有用 性を付加するものであり，消化液のさらなる利用促進のた めの有効な情報となるものと考える。 今後は, 圑場レベル での栽培試験において，さらにその有効性を評価していく 必要があるものと考える。

謝辞：本研究の材料として, ネコブセンチュウ 6 種を快 く提供して頂いた龍谷大学農学部の岩堀英晶博士, メタン 発酵消化液の入手にご協力頂いた鹿児島大学農学部の紙谷 喜則博士に深く感謝いたします.

\section{引用文献}

赤木功・㯪木直也 2014. 南九州の促成ピーマン産地の現地戋場にお けるネコブセンチュウ密度. 鹿大農学術報告 64: 1-6.

荒川裕介・赤木功・山本克巳 2003. 2-ヒドロキシビフェニルナトリ ウム塩を用いたインドフェノール法による農耕地土壤のアンモニ ウム態窒素の定量法.土肥誌 74: 657-659.

Bansal, R.K. and Bajaj, A. 2003. Effect of volatile fatty acids on embryogenesis and hatching of Meloidohyne incognita eggs. Nematologia Mediterranea 31: 135-140.

Browning, M., Dawson, C., Alm. S.R., Gorrës, J.H. and Amador, J.A. 2004. Differential effects of butyric acid on nematodes from four trophic groups. Applied Soil Ecology 27: 47-54.

畜産環境整備機構 2013. メ夕ン発酵消化液の濃縮・改変による野菜 栽培マニュアル. 1-85. http://www.chikusan-kankyo.jp/osuiss/syouka yasai/syouka_yasai_all_l.pdf (2015/11 閲覧).

Ferris, H., Venette, R.C., van der Meulen and Lau, S.S. 1998. Nitrogen mineralization by bacterial-feeding nematodes: verification and measurement. Plant and soil 203: 159-171.

畑田清隆 ·伊藤祥太 ·斉藤巧夫 · 浅野隆 1981. 線虫の簡便な生死判 定法. 東北工業技術試験所報告 13: 33-36.

井戸田幸子 · 浅野陽樹 · 霧村雅昭 · 杉元安寛 ·石井康之 2013. メ夕 ン発酵消化液の施用が南九州に抢けるトウモロコシーイタリアン ライグラス体系の収量性と飼料品質に及ぼす影響. 日草誌 58: 230240.

Ingham, R.E., Trofymow, J.A., Ingham, E.R. and Coleman, D.C. 1985. Interactions of bacteria, fungi, and their nematode grazers: effects on nutrient cycling and plant growth. Ecological Monographs 55: 119140.

Ishibashi, N. and Choi, D.R. 1991. Biological control of soil pests by mixed application of entomopathogenic and fungivorous nematodes. Journal of Nematology 23: 175-181.

石橋信義 2003. 線虫類の生存戦略. 石橋信義編. 線虫の生物学. 東京大 学出版会, 東京, pp.26-36.

石塚成宏.八木久義. 佐々木惠彦 1995 . 人工酸性雨が土壤中の細菌 に与える影響と団粒による保護効果. 日林誌 77: 589-595.

Johnston, T.M. 1959. Effect of fatty acid mixtures on the rice stylet nematode. Nature 183: 1392.
Jothi, G., Pugalendhi, S., Poornima, K. and Rajendran, G. 2003. Management of root-knot nematode in tomato Lycopersicon esculentum Mill., with biogas slurry. Bioresource Technology 89: 169-170.

上岡啓之・亀和田國彦 2011. 水稲コシヒカリに対するメタン発酵消 化液の基肥利用. 土肥誌 82: 31-40.

Katase, M., Kibo, C., Ushio, S., Ootsuka, E., Takeuchi, T. and Mizukubo, T. 2009. Nematicidal activity of volatile fatty acids generated from wheat bran in reductive soil disinfestation. 日本線虫学会誌 39: 53-62.

川島嘉内 1961. 土壤条件と線虫寄生との関係 2. 土壤粒子の大きさと ネコブセンチュウの寄生について. 北陸病害虫研究会年報 12: 9596.

Khan, Z. and Kim, Y.H. 2007. A review on the role of predatory soil nematodes in the biological control of plant parasitic nematodes. Applied Soil Ecology 35: 370-379.

古賀成司・古閑孝彦 1981. ネコブセンチュウの耕種的防除法に関す る研究. 熊本農試研報 7: 51-90.

久保周子 - 片瀬雅彦 - 清水喜一 ·加藤浩生 - 竹内妙子 2004 . トマト 土壌病害虫に対する土䁃還元消毒の効果. 千葉農総研報 3: 95-104.

Li, K.-Z., Inamura, T. and Umeda, M. 2003. Growth and nitrogen uptake of paddy rice as influenced by fermented manure liquid and squeezed manure liquid. Soil Sci. Plant Nutr. 49: 463-467.

Linford, M.B., Yap, F. and Oliveira, J.M. 1938. Reduction of soil population of the root-knot nematode during decomposition of organic matter. Soil Sci. 45: 127-140.

松中照夫 ·熊井実鈴 ·千徳あす香 2003. バイオガスプラント消化液 由来窒素のオーチャドグラスに対する肥料的効果. 土肥誌 74: 3138.

McElderry, C., Browning, M. and Amedor, J. 2005. Effect of short-chain fatty acids and soil atmosphere on Tylenchorhynchus spp. Journal of Nematology 37: 71-77.

Min, Y.Y., Sato, E., Shirakashi, T., Wada, S., Toyota, K. and Watanabe, A. 2007. Suppressive effect of anaerobically digested slurry on the root lesion nematode Pratylenchus penetrans and its potential mechanisms. 日本線虫学会誌 37: 93-100.

宮田尚稔・池田英男 2006. メタン発酵消化液が養液土耕におけるト マトの生育と果実収量に及ぼす影響. 土肥誌 77: 619-626.

Nagase, A., Kuwahara, Y., Tominaga, Y. and Sugawara, R. 1982. Nematicidal activity of akylamine against the pine wood nematode, Bursaphelenchus lignicolus. Agric. Biol. Chem. 46: 167-172.

Nahar, M.S., Grewal, P.S., Miller, S.S., Stinner, D., Stinner, B.B., Kleinhenz. M.D., Wszelaki, A. and Doohan, D. 2006. Differential effects of raw and composted manure on nematode community, and its indicative value for soil microbial, physical and chemical properties. Applied Soil Ecology 34: 140-151.

中野明正 ·上原洋一 2003. かん水同時施肥栽培におけるコーンス ティープリカーおよびメタン発酵消化液の利用がメロンの生育お よび収量に及ぼす影響. 園学研 2: 175-178.

中園和年 1989. 廐肥施用によるトマトのサツマイモネコブセンチュ ウ害の軽減効果. 日本線虫研究会誌 19: 38-45.

中園和年 - 佐野善一 - 荒城雅昭 - 伊藤祐二郎 1989. 土壤型とトマト のサツマイモネコブセンチュウ被害 (1). 日本線虫研究会誌 18: 45-53.

中園和年 - 佐野善一 - 荒城雅昭 - 伊藤祐二郎 1990. 土壤型とトマト のサツマイモネコブセンチュウ被害 (2). 日本線虫研究会誌 20: 
$37-43$.

Nishikawa, T., Li, K., Inoue, H., Umeda, M., Hirooka, H. and Inamura, T. 2012. Effects of long-term application of anaerobically-digested cattle manure on growth, yield and nitrogen uptake of paddy rice (Oryza sativa L.), and soil fertility in warmer region of Japan. Plant Prod. Sci. 15: 284-292.

Nishikawa, T., Kido, K., Li, K., Inoue, H. and Inamura, T. 2013. Temporal growth inhibition of rice plant and growth recovery observed under application of anaerobically-digested cattle manure. Plant Prod. Sci. 16: $154-165$.

Nishikawa, T., Li, K. and Inamura, T. 2014. Nitrogen uptake by the rice plant and changes in the soil chemical properties in the paddy rice during yearly application of anaerobically-digested manure for seven years. Plant Prod. Sci. 17: 237-244.

農林水産省 2007. 家畜排せつ物利用の促進を図るための基本方針. http://www.maff.go.jp/j/press/2007/pdf/20070330press_6c.pdf (2015 /11 閲覧).

農林水産省 2015. 畜産環境をめぐる情勢. http://www.maff.go.jp/j/chikusan/ kankyo/taisaku/pdf/meguru_jousei.pdf (2015/11 月閲覧).

農村工学研究所 2012. メ夕ン発酵消化液の畑地における液肥利用一肥料 効果と環境への影響一. http://www.naro.affrc.go.jp/nkk/introduction/ files/ekihiriyou.pdf. (2015/11 閲覧).

大嵩洋子・若梅均 2006. 千葉県長生地域に抢けるトマトでの熱水土 壤消毒技術普及の取り組み. 野菜茶業研究集報 3: 1-6.

大林延夫 1989. ダイコンを加害するキタネグサレセンチュウの防除 技術に関する研究. 神奈川県園試研報 39: 1-90.

岡田浩明 2002. 土壤生態系における線虫の働き-特に無機態窒素の
動態への関わり一. 根の研究 11: 3-6.

佐野善一 2014. ベールマン法. 水久保隆之.二井一禎編. 線虫学実験. 京都大学学術出版会, 京都. 192-193.

佐野善一・中園和年 1997a. 黒ボク土壤の団粒内部と外部におけるサ ツマイモネコブセンチュウ2期幼虫の生存の違い. 土と微生物 49 : 1-7.

佐野善一・中園和年 1997b. 黒ボク土壤の団粒構造がサッマイモネコ ブセンチュウ 2 期幼虫の生存に及ぼす影響. 土と微生物 49: 9-16.

清水恵美 · 増田大祐 ·西村康平 ·橋本尚 2006. 砂丘地における土壤 消毒後のガス難透過性フィルムの利用がメロンのネコブセンチュ ウの発生抑制に及ぼす影響. 石川農総研報 27: 25-31.

田場聡 - 安次富厚 - 島袋由乃 - 與那覇美沙 · 高良綾乃 · 永松ゆきこ . 諸見里善一 2012. 植物寄生性線虫類に対するアワユキセンダング サ煮沸抽出液の抗線虫活性と抽出液の活性安定性. 雑草研究 57: $1-6$.

田端健二 1979. 水生生物に対する各種水質污染物質の半数致死濃度 と長期影響限界濃度との関係. 東海水研報 98: 1-21.

徳田進一 - 田中康男 - 東尾久雄 - 村上健二 · 相澤証子 - 浦上敦子 . 國久美由紀 2010. キャベッの露地栽培におけるメタン発酵消化液 の効果的な施用方法. 土肥誌 81: 105-111.

梅津一考 ·山縣眞人 · 岸本正 - 谷昌幸 - 林峰之 · 三崎卓也 2003. 乳 牛ふん尿と有機性廃棄物による混合メタン発酵消化液の秋蒔き小 麦 (ホクシン)への施用. 農作業研究 38: 199-205.

吉田睦浩 1992. サッマイモネコブセンチュウ. 中園和年編. 線虫研究 の歩み一日本線虫研究会創立 20 周年記念誌一. 日本線虫研究会, 茨城. 133-137.

\section{Reducing Damage Caused by Root-knot Nematodes by Applying Methane-fermentation Liquid from Livestock Waste Slurry to} Soil : Isao Akagi and Naoya Chishaki (Fac. of Agr., Kagoshima Univ., Kagoshima 890-0065, Japan)

Abstract : The effect of methane fermentation liquid obtained from livestock waste slurry (MFL) on the activity of root-knot nematodes (Meloidogyne spp.) was evaluated. On the day after preparation, MFL contained $1.86 \mathrm{~g} \mathrm{~L}^{-1}$ of ammonium nitrogen which is reported to have nematocidal activity. However, the ammonium nitrogen content decreased with the lapse of storage time. More than $90 \%$ of the population of M.incognia was immobilized by adding the five-times-diluted MLF solution to a suspension of M.incognita. This immobilization effect was also observed in other Meloidogyne spp.: M. arenaria Honshu-type, M. arenaria Okinawa-type, M.hapla, M.javanica and M.microcephalus. The population of M.incognita in soil was significantly reduced by addition of $120 \mathrm{~mL} \mathrm{~kg}^{-1}$ (equivalent to $60 \%$ of maximum water-holding capacity) MLF to soil in Sand-dune Regosol infested with M.incognita. However, this effect was not observed clearly in Gray Lowland soil and Andosol. The amount of egg masses produced by M.incognita was reduced to less than $25 \%$ of that in the control by applying $70 \mathrm{~mL} \mathrm{~kg}^{-1} \mathrm{MLF}^{\text {(containing } 200 \mathrm{mg} \mathrm{NH}}{ }_{4}^{+}$-N) to the soil of nematode-infected Sand-dune Regosol in the pot experiment with tomato seedling.

Key words : Methane-fermentation Liquid, Reducing damage, Root-knot nematode. 